\title{
Professional Sports and Urban Development: A Brief Review of Issues and Studies
}

\author{
Harrison S. Campbell, Jr.*
}

\begin{abstract}
The relationship between professional sports and cities is an important public policy issue that has received growing attention in the academic literature. Investment in sports facilities is frequently rationalized on the basis of economic impact and positive spillover effects to cities and regions, yet there is mounting suspicion that professional sports have only a marginal impact on their surrounding area. Why are professional sports so important? What factors help explain the recent stadium construction boom? What promise do sports and new stadium construction hold for urban development? This paper reviews recent literature on these subjects and highlights some of the conceptual and empirical difficulties in assessing the role of sports in urban development.
\end{abstract}

\section{INTRODUCTION}

One does not have to look very hard at newspaper headlines to know that millions of dollars, both public and private, are currently being spent on the construction and renovation of professional sports facilities. Recently, new or expanded facilities have been built, or are being planned, in Anaheim, Baltimore, Charlotte, Chicago, Cleveland, Denver, Detroit, Houston, Milwaukee, San Diego, San Francisco, Seattle, and a host of other cities in the U.S. and Canada. No city or professional sports league is immune to the sports facility construction boom, with most facilities ranging in cost from $\$ 200$ million to $\$ 500$ million. The estimated cost of these facilities to both the public and private sectors can be staggering. Keating (1999) has stated that "...During the 20th century, more than $\$ 20$ billion (in 1997 dollars) has been spent on major league stadiums and arenasincluding at least $\$ 14.7$ billion in taxpayer subsidies. For the rest of this year and the next several years, another conservative estimate points to more than $\$ 13.5$ billion more being spent on new major league facilities-including more than $\$ 9$ billion in taxpayer subsidies." Similarly, Bast (1998) quotes Roger Noll and Andrew Zimbalist, two leading experts in the economics of professional sports, as stating that "industry experts estimate that more than $\$ 7$ billion will be spent on new facilities for professional sports teams before 2006. Most of this $\$ 7$ billion will come from public sources." For any newly constructed or renovated professional sports facility, it is now almost standard practice that local and state governments shoulder approximately two-thirds of the direct costs of facility construction.

\footnotetext{
"Department of Geography and Earth Sciences, University of North Carolina at Charlotte. This paper benefited from the comments and suggestions of Owen Furuseth, J. Dennis Lord, Jack Sommer, and two anonymous referees. An earlier draft of this paper was presented at the 38th annual meeting of the Southern Regional Science Association, April 15-17, 1999, Richmond, VA.
} 
Stadiums and arenas represent the primary connection between teams and the cities in which they play (Danielson 1997). These facilities are icons on the urban landscape that act as symbolic reminders that cities are in the "big leagues" and are places of regional, national, and even international importance. But why are professional sports so important and why has the stadium or arena become the linchpin in hosting a major league (and increasingly minor league) franchise? What factors have contributed to the growth of public sector involvement in sports facility construction? What does the general public gain from these investments and are they worth it? This paper reviews recent literature on these subjects, highlighting some of the conceptual and empirical difficulties in assessing the role of sports in urban development.

\section{WHY ARE SPORTS SO IMPORTANT?}

To even the most casual observer, professional sports command a great deal of attention. As in many other countries, professional sports in the United States have enjoyed high and growing levels of attendance, participation, and enthusiasm from the general public. The social importance placed on professional sports is surely disproportionate to their importance in the national economy. In cities hosting professional sports teams, daily newspapers and local newscasts typically devote 20 percent or more of their coverage to the reporting of sports news. Even in small towns with no professional sports, a similar percentage of the local weekly paper is devoted to covering recreational and organized sports in local schools.

To understand why sports hold a special place in American society one must realize that, more than with most industries, people take pride in professional sports as external representations of their communities, cities, and nation. These types of intangible benefits are frequently touted by present-day proponents of professional sports as instilling a sense of place among residents of a community. Though the value of intangible benefits is, at best, difficult to measure, sports are undoubtedly an important cultural thread in the fabric of society. It is commonly believed that sports, and their symbolic representation of place, provide a social focal point around which diverse groups of people relate and exchange opinions and ideas. As a common point of shared interest, it is also thought that sports provide a collective consciousness, which when connected to a specific locale serves to enhance sense of place and our attachment to community (Stone 1981).

Few other industries have performed this function, and Euchner (1993) quips that it is difficult to imagine residents of Baltimore rooting for the Eskay meat company in the same way they do for the Orioles. Despite the unstable nature of many sports teams and leagues in their formative years, professional sports are a decidedly urban pastime. Because professional sports take place almost exclusively in our largest cities and metropolitan areas, and because leagues ensure their teams certain "rights" based on geographic market areas, professional sports are also said to be both hierarchical and territorial (Bale 1994). 
"The city was the place where sport became rationalized, specialized, organized, commercialized, and profesșionalized" (Riess 1989, p. 1). In fact, the history of sports in urban America is intimately connected with the processes of urban growth, development, and change. Some authors have even suggested that sports not only reflected the processes of urbanization and industrialization, but fostered such change by facilitating the emergence of values concerning work and leisure that were consistent with the development of industrial cities in the late 19th and early 20th centuries.

Karp and Yoels (1990) contend that the twin processes of urbanization and industrialization promoted the rise of professional sports and, in turn, sports helped foster the growth of industrial cities. As industrialization and technological innovation changed the nature of production, millions of immigrants and rural farm workers migrated to American cities. Industrialization simultaneously brought both a more regimented form of work and periods of leisure that had not been part of agrarian life. Baseball, in particular, was thought to teach the newly urbanized workforce important lessons that were consistent with the needs of the industrial workplace: that competition as well as cooperation, individualism as well as teamwork, were important; that discipline, the meaning of rules in human conduct, and patterns of and response to authority, were part of modern life; that there should be a balance between individual and group achievement; and that there is a relationship between efficiency and excellence. Baseball was thought to teach these lessons and, as such, fostered a "mutually transformative relationship between sports and the growth of American cities during the 19th and early 20th centuries" (Karp and Yoels 1990, p. 79). Thus, in addition to being compatible to the economic development of cities, sports also provided a basis for social and institutional development.

The impact of sports on the economic, social, and institutional development of cities, along with their purely recreational function, helps explain some of the importance society attaches to sports and underpins many of the intangible benefits sports promoters extol. The fact that Americans have social, emotional, spatial, and nostalgic ties to professional sports is not lost on teams, owners, and leagues in their quest for new or enhanced playing facilities. As the economic development potential of sports comes into question with greater frequency, promoters and boosters turn to the value of "intangibles" in making their case for public support of their facilities. Many authors contend that to view sports solely in terms of their economic impact and ignore their role in enhancing civic pride and identity is shortsighted. Many of the same authors also hold that "in order for teams to truly serve this function of community representation, they must exhibit some stability" and that "as sport is conducted more as an industry under economic considerations, it becomes increasingly difficult for sport to serve the cultural function of creating community integration" (Karp and Yoels 1990, p. 93). 


\section{WHY THE CONSTRUCTION BOOM?}

It is unclear that sports can still perform the social function they did in previous decades, and increasing numbers of citizens, politicians, and analysts are also questioning the importance of sports-and the associated public subsidiesto the economic development of cities. However, public sector involvement and the construction of municipally owned stadiums and arenas are nothing new. Prior to the 1930s, most stadiums were privately owned, being built before World War I. In 1933, when Cleveland built Municipal Stadium, the only publicly financed stadiums were the Los Angeles Coliseum and Soldier Field in Chicago, built in hopes of attracting the Olympic Games. The Great Depression and World War II prevented teams from renovating and refurbishing their facilities such that by 1950, many were in desperate need of repair.

The advent of municipally financed stadiums has been traced to the Boston Braves, who moved to Milwaukee in 1953 where they set team attendance records in their new facility built by the city (Danielson 1997; Riess 1998; Sullivan 1998). Because most team revenue at the time was generated through ticket sales, new publicly owned stadiums had obvious appeal to team owners. In 1954 the St. Louis Browns moved to Baltimore; 1955 saw both the Washington Senators move to Minnesota and the Philadelphia Athletics relocate to Kansas City; and in 1960 the Giants, who had left the Polo Grounds in New York, moved into their new stadium at San Francisco's Candlestick Park. All of these facilities were built by the public sector, setting in motion a seemingly irreversible trend. Danielson (1997) shows that between 1960 and 1972 the median age of playing facilities declined substantially in all the major league sports. In 1960, the median age of major league baseball parks was nearly 50 years, but had dropped to 10 years by 1966; in the NFL the median age dropped from about 36 years to 10 years between 1961 and 1971; and NBA facilities declined in age from 35 years to 5 years between 1966 and 1967.

By the mid-1990s, over half of the major league facilities had been built during the 1960s and 1970s. Aging facilities, coupled with "economic obsolescence," has sparked demands by teams and their owners to replace existing facilities. The notion of economic obsolescence is based in new revenue-enhancing features of the modern sports facility. These enhancements largely revolve around sky boxes and other luxury seating. The revenue generated from them are important to teams because they are not shared with their leagues in a manner similar to gate receipts or media contracts. Many small-market franchises with stadiums and arenas built before the most recent wave of luxury seating claim that these new facilities are needed to generate sufficient revenue to field competitive teams. Teams in larger markets also make this claim and without these enhancements, they argue, their teams will suffer. The public sector has become involved because (a) most franchises are not willing to incur the total costs of construction, which now easily range between $\$ 200$ and $\$ 300$ million; and (b) teams threaten relocation if new facilities are not developed. With escalating construction costs and threats of 
relocation, it is not surprising that by 199581 percent of all major league stadiums and arenas were publicly owned, with the greatest percentage ( 90 percent) found in the NFL (see Danielson 1997, p. 225). The total or partial subsidy to professional sports franchises in the form of new stadiums and arenas is rationalized as an investment in economic development. The extent to which real development benefits flow from these investments, however, continues to be a hotly debated issue.

\section{SOME GENERAL DEVELOPMENT ISSUES}

Sports teams, arenas, and stadiums are purported to attract visitors to the places in which teams play, stimulate a variety of local businesses, create jobs and expand local income, enhance the quality of life for local residents, and, in some cases, provide the marginal benefit that might attract a relocating employer. To be sure, sports are seen as one ingredient in the development of world class cities. It should be noted that a host of other factors are also important in becoming a world class city, such as quality schools, museums, libraries, symphonies, universities, medical centers, and the like. For sports to serve as a platform for economic development, they must serve an export function by attracting visitors and revenue from outside the region, serve an import substitution function by retaining recreational expenditures that would otherwise have been spent outside the region, and/or otherwise provide benefits in the form of positive externalities. For public sector investment in sports facilities to make economic sense, sports facilities must provide an adequate return on public sector investment, comparable to the returns made on other investments.

The attraction of extraregional visitors to a city is perhaps the most common ground on which the economic impact of big league sports is based. Luring a professional team, or building state-of-the-art facilities, is expected to elevate the level of local economic activity. Teams have sizable payrolls, purchase some equipment from local businesses, employ residents in a variety of positions, and (usually) pay rent for the use of their stadium or arena. Visiting teams purchase meals, transportation, and hotel rooms during home games, and attendees of the games spend money on tickets, parking, concessions, souvenirs, and in local restaurants, bars, and retail establishments. While it is clear that this spending can be sizable, what is less clear is the extent to which this spending represents new injections to the local economy and thus represents net economic gains to the community. Alternatively, a development strategy based on investment in sports might serve to keep some recreational spending in the region that might otherwise have been spent in another area. The landing of an NFL franchise in Charlotte, NC, for example, might keep some spectators from traveling to Atlanta to see the Falcons, thereby keeping recreational spending in the Charlotte region. To the extent that recreational expenditures are retained, economic impacts are realized through the process of import substitution.

Mostly, from the benefit side of the development equation, it is possible that some people realize benefits in the form of externalities produced by professional sports. These externalities might be derived from the value residents 
place on following a local team in the newspaper or having a greater sense of community attachment due to the presence of a team, even though they do not directly produce or consume sporting events. Interestingly, though not typically an explicit part of sports developers' arguments supporting facility construction, Noll and Zimbalist (1997) suggest that this might be the most solid ground on which to justify stadium subsidies. "...[F]or a stadium that receives a subsidy of $\$ 250$ million in a metropolitan area of five million, per capita capital costs are $\$ 50$, and the per capita annualized cost of servicing the debt (interest plus amortization) to finance the stadium is about $\$ 5$. It does not vastly stretch credulity to suppose that, say, a quarter of the population of a metropolitan area derives $\$ 20$ per person in consumption benefits annually from following a local sports team" (Noll and Zimbalist 1997, p. 58). Similarly, estimates by Hamilton and Kahn (1997), with regard to the Camden Yards facility, indicate that such benefits would only have to amount to $\$ 12$ per household in Baltimore after accounting for real increases in sports-related tax revenue, while Baim (1990) shows that a typical subsidy amounts to approximately $\$ 20$ per capita.

The issue of consumer surplus is perhaps the most neglected aspect in determining the costs and benefits of new stadium construction/renovation. Baim (1990) presents estimates of the net accumulated value of fourteen baseball and football stadiums noting that, with the exception of Dodger Stadium in Los Angles (the last privately financed facility at the time), the net accumulated value of stadiums ranged from $-\$ 836,000$ to $-\$ 70.4$ million. Although it appears that most teams are able to cover annual operating costs, it is doubtful that most facilities cover their fixed costs. While the inclusion of both operating and fixed costs are clearly important to a cost-benefit analysis, Irani (1997) contends that the treatment of consumer surplus and welfare gains from stadium construction have been left unexamined in the literature. "If there is a difference between a person's willingness to pay for a ticket to a sporting event and the actual price paid for the ticket, then a positive amount of consumer surplus is generated" (p. 241) [and] "if net consumer surplus and other financial benefits of a stadium exceed its cost, the city should consider subsidizing its construction or renovation" (p. 239).

To that end, Irani (1997) estimates a fixed effects Marshallian demand function for all baseball stadiums between 1972 and 1991 using data on ticket prices, attendance, population, per capita income, and the team's winning percentage. The results indicate that the demand for baseball games is (a) inelastic and normal (a 10 percent increase in ticket price reduces demand by 3.4 percent); (b) insensitive to population change (a 10 percent change in population changes attendance by only 1.2 percent); and (c) most responsive to changes in per capita income and teams' winning percentages (with a 10 percent change in either associated with a 7.8 percent and 9.6 percent change in attendance, respectively). Integrating the estimated demand equation produced estimates of consumer surplus for 1985 that ranged between $\$ 2.2$ million (Cleveland Indians) and $\$ 54.1$ million (Los Angeles Dodgers), with an average consumer surplus across all stadiums of $\$ 18.4$ million. Taking an average of fixed and variable stadium costs 
of five recent stadium projects (Camden Yards, Jacobs Field, The Ballpark in Arlington, Coors Field, and Comiskey Park) and straight-line depreciation of a 30year bond issued at 7 percent, the annual total cost of a stadium is approximately $\$ 27$ million. Assuming that stadium rent is sufficient to cover operating costs, the estimates of consumer surplus suggest that the annual net benefit of a stadium ranges between $-\$ 19.1$ million and $+\$ 32.8$ million. It is intimated that these estimates should be added to the economic impacts associated with multiplier analyses based on the export promotion or import substitution effects of professional sports and their facilities.

The importance of export promotion and import substitution to those attempting to attract public subsidy in the construction of sports facilities is that these forms of economic impacts lead to subsequent rounds of spending within the local economy, thereby generating additional jobs and income in the area. If export promotion or import substitution constitute the direct impact of sporting events, the additional rounds of spending that are stimulated by the direct impacts constitute a set of indirect impacts. The magnitude of the indirect effects is frequently crucial in garnering local support for subsidizing sports facilities. The indirect, or multiplier, effects of team and visitor spending are estimated with economic models designed to capture subsequent rounds of spending in the local economy. Indeed, multiplier analysis is the main objective of most economic impact studies and estimates of indirect benefits from professional sports are known to vary widely (see below).

Many studies of the development impacts from professional sports suffer from two fundamental oversights. The first relates to what some economists call the "realignment" of leisure spending, and the second stems from omitting the relevant costs of stadium and arena construction. There is precious little research directly investigating the extent to which one form of recreational spending simply serves to substitute for another. Households have limited time and financial resources for recreational activity and spending. Unless the attraction of a sports team or the construction of a new stadium generates entirely new spending, it is likely that much of the local spending by sports fans simply serves to reallocate spending that would have taken place elsewhere in the local economy. In choosing to attend a basketball game, most spectators are forgoing other leisure opportunities such as attending the symphony or going to the theater. If a spectator has a meal at a local restaurant before attending a game, it is likely that, in the absence of the game, the fan would have purchased a similar meal elsewhere in the local area. In such cases, the sporting event has simply served to shift the timing and location of the expenditure, but may not have generated additional new spending in the aggregate. Indeed, what the restaurant near the stadium gains may well be lost by a restaurant located elsewhere in the city. This spending realignment, or substitution among leisure spending options, represents no net gain in regional economic activity. These realignment issues become increasingly important as the proportion of spectators from the local area increases. 
Noll and Zimbalist (1997) also note that a good impact study should not simply calculate the benefits of stadium construction, but should assess the costs of construction as well. Generally, these costs include both the initial costs and the costs of operation. The relevant costs, however, are not the financial costs to local governments of construction and operation, but the opportunity costs of the investment, which can measured in terms of the value of the investment in its next best alternative. In other words, "the opportunity foregone in building a stadium is not the cost of the stadium, but the benefits from the other ways this money could be spent (including tax reductions)" (Noll and Zimbalist 1997, p. 62). Given the current expense of stadium construction, the opportunity costs of sports facilities can be significant.

Suppose that the costs of debt service and depreciation plus operating costs on a new $\$ 200$ million basketball arena in Seattle are $\$ 20$ million per year over the course of 30 years. Now suppose that the costs of hiring an entry-level police officer in Seattle is $\$ 25,000$ per year and that fringe benefits amount to 50 percent of salary, for a total cost of $\$ 37,500$ per year. If providing additional police protection is a high priority for the city, then the same $\$ 20$ million expenditure could put 530 additional entry-level police officers on the Seattle police force. If entry-level teacher salaries are governed by a similar wage structure, and on average there are 25 students per public school teacher, then for the costs of the arena, 530 public school teachers could be educating 13,250 pupils in the local school system. Likewise, in North Carolina the same resources could pave 32 lane miles of road annually (not including right-of-way costs), or approximately 765 lane miles over a 30-year period (Walden 1998). The value of these alternatives should be weighed against the value of public sector subsidy to other investments.

To the extent that professional sports serve as a regional export, provide recreational opportunities to local residents, and keep spending in the region that would otherwise be spent elsewhere, and the opportunity costs of public sector investment are deemed acceptable, then real net gains in economic development from professional sports can be realized.

\section{EMPIRICAL EVALUATIONS}

Many proponents of professional sports rest their assertions on the ability of teams and facilities to generate positive economic gains for the host community. In this section a few case studies examining this proposition are reviewed. Before looking at these studies, however, we should attempt to put professional sports in context. As noted above, the importance society places on professional sports is surely disproportionate to its economic significance, yet the construction of stadiums and arenas is frequently rationalized on the grounds that investment in sports, particularly in central cities, will revitalize downtowns, spur additional private sector investment, and create jobs that will help drive the local economy.

How big an industry is professional sports? Rosentraub (1997a) reports that across the U.S., the proportion of private sector employment and payroll accounted for by professional sports in counties with 300,000 or more residents in 
1992 amounted to only 0.06 percent and 0.10 percent, respectively. As shown in Table 1, the direct contribution of professional sports (SIC 794, which includes racing and track operation) increases with city size. Among counties with 300,000 to 500,000 , the contribution of professional sports to private sector employment and payroll was 0.03 percent and 0.14 percent, respectively, in 1992. The same figures for counties with populations over 2 million were 0.06 percent and 0.52 percent. Obviously, the generous payrolls supported by professional sports contributes more to regional income than the employment levels would suggest, though it is unclear exactly how much of this payroll is actually recirculated throughout the local economy.

\section{TABLE 1}

The Percentage of Employment and Private Sector Payroll by County Populations, 1992

\begin{tabular}{|c|c|c|c|c|}
\hline \multirow[b]{2}{*}{ Industry } & \multicolumn{4}{|c|}{ Population of County } \\
\hline & $\begin{array}{c}300,000- \\
500,000 \\
(n=66)\end{array}$ & $\begin{array}{c}500,001- \\
1,000,000 \\
(n=65)\end{array}$ & $\begin{array}{c}1,000,001- \\
2,000,000 \\
(n=22)\end{array}$ & $\begin{array}{c}\text { More than } \\
2,000,000 \\
(n=8)\end{array}$ \\
\hline $\begin{array}{l}\text { Professional sports employment } \\
\text { as a percent of total employment }\end{array}$ & $0.03 \%$ & $0.06 \%$ & $0.08 \%$ & $0.06 \%$ \\
\hline $\begin{array}{l}\text { Professional sports payroll as a } \\
\text { percent of private sector payroll }\end{array}$ & $0.14 \%$ & $0.13 \%$ & $0.24 \%$ & $0.52 \%$ \\
\hline
\end{tabular}

Source: Rosentraub (1997a), Table 4-2, p. 143.

Rosentraub (1997a) goes on to illustrate that the counties with the largest concentration of sports-related employment were found in Summit, $\mathrm{OH}$ ( 0.35 percent), Fulton, GA ( 0.32 percent), and Baltimore City ( 0.26 percent). Among the local areas for which payroll data were available, St. Louis City ranked the highest at 0.74 percent of payroll. Rosentraub notes, however, that while percentages provide an accurate description of the relative importance of professional sports to a local economy, these numbers obscure the absolute values. For example, topping the list in terms of total sports employment in 1992 was Cook County, IL, with its five major league teams and racetracks employing nearly 3,700. Of the top 14 counties examined, only three (Fulton, GA, Cook, IL, and Oakland, MI) employed more than 1,000 in the sports sector. As discussed below, even these numbers can be deceiving, but they indicate the direct magnitude of sports-related employment across the central counties of major metropolitan areas. Given the size of these direct employment effects, it is not surprising that several empirical studies attempting to measure the ex post economic impact of professional sports find little relationship between overall economic development and (a) the presence of professional sports franchises; and (b) new stadium and arena construction.

Robert Baade (1987), a noted sports economist, has demonstrated that professional sports contributes little to metropolitan area income growth. Examining nine SMSAs hosting at least one big league sports franchise between 1965 and 1983, Baade and Dye (1990) regressed real (1982 dollars) aggregate income against SMSA population, new stadium construction or renovation, dummy variables indicating whether the SMSA hosted professional football or baseball, and a trend variable. Similar equations were estimated for a dependent variable expressed as 
the SMSA's share of multistate personal income. Pooling all data together they concluded that "after controlling for the effect of population and time trend, the presence of a new or renovated stadium has an insignificant impact on area income in all but one of the metropolitan areas" (Baade and Dye 1990, pp. 9-10). Examining the impact of professional sports on retail sales, they find that none of the sports variables were significantly related to retail sales, a result also obtained by Zipp (1997). Only in Seattle, with the arrival of a new NFL franchise, was there a significant relationship between aggregate income and stadium construction. When they examined the impact of stadiums and arenas on the SMSA share of income they find that, overall, the impact of stadium construction and/or renovation significantly reduces the metro area's share of regional income. In four specific cases (Cincinnati, Detroit, Kansas City, and Tampa Bay), construction/ renovation significantly contributed to a reduction in the share of income accruing to SMSAs; in two cases (New Orleans and Seattle), construction/renovation contributed to an increasing share of regional income.

Though Baade and Dye (1990) note that the inclusion of population and trend variables control for incomes that are likely to be higher in larger metro areas and other changes in local economies not captured by the equations, it is still arguable that their models were underspecified given substantial structural change in these economies over the sample period. Though the aggregate impact of sports on metropolitan area income may be small, correlation should not be confused with causality. Further, it should be noted that income is reported on a place of residence basis and includes a variety of sources not related to the region generally (such as transfer payments, rents, and dividends). Since wage earners work outside their region of residence with some frequency, a similar measure, such as earnings, would more closely approximate development and job creation of professional sports and be more conceptually appropriate. In fact, Baim (1990) questions the use of personal income as an appropriate measure of the impact of stadium investment. In a study measuring the relationship between the number of jobs and the presence of a major league franchise, he found that a "statistically significant increase in employment in both the service and non-agricultural sectors of the economy was related to the presence of a major league franchise... [though the] precise increase depended upon the size of the community" (Baim 1990 , p. 14). Consequently, because each case is unique, "any attempt at generalization is likely doomed to failure" (Baim 1990, p. 14).

As a general rule, changes in per capita income are considered a superior measure of economic development. Expanding an earlier analysis to cover 30 metropolitan areas, Baade (1996) employs such a measure and regresses it on a metro area's number of stadiums that are less than 10 years old and the number of franchises in the region over the 1958-1987 period. A similar (not identical) equation was also estimated to explain a city's share of employment in amusement and recreation services (SIC 79). Results for the per capita income equations were generally not significant (teams and new stadiums had no significant impact on changes in per capita income) except in Indianapolis (positive relationship) where 
the city had pursued a major multiyear investment in sports-dependent economic development projects (Rosentraub 1997b; Rosentraub et al. 1994) and in Baltimore where the presence of a team was significantly correlated with a reduction in per capita income growth. The presence of teams and stadium investment also had no general impact on employment in SIC 79 (or SIC 794). Examination of the individual city results shows that employment shares in these industries were positively related to the franchise and stadium variables in six metropolitan areas and negatively related in four. From the pooled results it was concluded that "adding a professional sports team or stadium to a city's economy appears to realign leisure spending rather than adding to it and is therefore neutral with respect to job creation...[and that] the fan base supporting professional sports appears to be insufficiently foreign to the city to contribute significantly to metropolitan economic activity" (Baade 1996, p. 14).

An advocate of sports-related development strategies, Chema (1996) makes a 10-point argument to highlight that sports-related development in the 1990s is qualitatively different from that covered in Baade's (1996) sample. Much of his critique questions limiting the dependent variable to employment in one sector, measuring development in relation to other cities, and whether spending on sports disperses beyond the stadium environs any faster than other places of business. Stadiums' value as a catalyst for development, argues Chema (1996), "depends on where they are located and how they are integrated into a metropolitan area's growth strategy" (p. 19). Indeed, current thinking among sports advocates is that the trend toward downtown stadium locations, integrated with mixed land use plans that are architecturally compatible with the pedestrian scale, hold more promise for realizing economic benefits than the suburban, multipurpose facility of the 1970s. Lack of integration has been one the major criticisms of the $\$ 650$ million improvement plan for Yankee Stadium, which called for the creation of a "Yankee Village." To expand the availability of parking, the city proposed to build a bridge across the Harlem River and construct a transit station within the stadium such that spectators would never actually set foot in the Bronx (Fainstein and Stokes 1998). This clearly limits (eliminates) the possibilities for spin-off activity that is desperately needed in the area. The alternative is a nearly $\$ 1$ billion facility on the West Side of Manhattan, which has the advantage of creating synergy with surrounding retail, eating and drinking establishments, and entertainment facilities, but may produce unacceptably high levels of congestion.

Congestion and parking considerations are not unique to New York. In San Diego, for example, a $\$ 411$ million facility for the Padres is planned in the downtown district of East Village, which is in close proximity to both the Gaslamp Quarter, a popular historic area, and the city's convention center. While this model of stadium development is consistent with the trend toward centrally located sports and entertainment facilities, environmental impact studies of the project reveal a shortage of 13,000 parking spaces within the downtown area (San Diego Union-Tribune, October 5, 1999). Entrepreneurs and patrons of the Gaslamp Quarter have expressed concern that the current parking shortage will be compounded on 
game days. The problem is further exacerbated by plans to expand the nearby convention center-a plan that contains no provisions for additional parking. Interestingly, one proposed solution in San Diego involves utilizing the second largest parking lot in the country—at the old Qualcomm Park, which the new stadium is to replace-and let spectators take a seven-mile trolley ride (about 25 minutes) to the new stadium (San Diego Union-Tribune, October 2, 1999).

In each case, the rationale for a downtown sports facility revolves around synergistic effects and the development or enhancement of an entertainment district. Despite the fact that the trend toward downtown locations is more pronounced for NBA and NHL facilities (Newsome and Comer 2000), many advocates hold up Coors Field in Denver, Jacobs Field in Cleveland, and Oriole Park at Camden Yards in Baltimore as examples of how stadium-based development can be realized. All of these facilities were opened between 1992 and 1995 and are architecturally integrated with the surrounding area. Limited parking facilities promote this integration, and the historic district adjacent to Coors Field has seen a 70 percent increase in the number of restaurants and an increase in the number of residential units from 270 to 700 , with future plans to build a $\$ 30$ million retail complex (Santee 1996).

These observations might actually raise more questions than they answer. For example, to what extent has the growth in restaurants and bars around these facilities been accompanied by similar declines in other parts of the city? To what extent have these investments crowded out other investments, and what are the opportunity costs of this crowding out? Is it possible that economic development can be associated with teams and stadiums, but that the spatial scale at which this takes place is smaller than that addressed by prior studies of metropolitan areas?

This latter question may lie at the heart of the current debate. While it is difficult to measure substitution and realignment effects of recreational spending, it is well known that the parameters of an economic impact study are related to the spatial scale at which it takes place (Zimbalist 1998). Those who support the notion that economic development benefits are highly localized to areas immediately surrounding a facility can claim that much, if not all, visitor spending is a net gain to the area. The resulting multiplier effects, however, will be small. As the size of the region increases, it becomes much more likely that visitor spending at sporting events substitutes for other leisure spending, thereby reducing the net gain (direct impact) to the local economy. On the other hand, as the study area increases in size, so too do the multiplier effects associated with that spending. Because there is a trade-off between the size of the impacted area and the size of multiplier, it is not clear, a priori, what spatial scale should be evaluated.

Indianapolis has pursued a conscious export promotion sports-related development strategy and it provides a good case study concerning the effects of sports development at different spatial scales. Rosentraub (1997b) has examined data at several spatial scales to address this question, noting that vast sportsrelated investment in Indianapolis was specifically aimed at revitalizing the central business district by attempting to reverse, or slow, the rate of household and 
commercial suburbanization. From 1974 to 1990, Indianapolis made several major central city investments, many of which were sports related. Examining trends in both population and selected economic sectors at four geographic scales-central business district (CBD), balance of city, balance of county, and balance of regionRosentraub (1997b) demonstrates that the city was not able to reverse the trend of decentralization in population and employment over the 1970-1990 period. Although the city's share of population and employment declined over each time period examined, population change in Indianapolis did stabilize between 1990 and 1995, though employment gains realized between 1985 and 1990 were all but lost by 1995. Unfortunately for proponents of sports-based development, similar results were found in the aggregate for cities with and without downtown sports facilities, though from 1990 to 1995 "cities with facilities in their downtown areas did better, suffering a decline of only 4.7 percent as compared with the 7.4 percent decline in jobs in the CBDs in other cities" (Rosentraub 1997b, p. 202).

If economic development is associated with rising per capita income and greater factor productivity, then sports-induced development should also be associated with rising land values around the location of stadiums and arenas. Beard et al. (n.d.) addressed this question in the Charlotte, NC, region by examining changes in real estate values before and after the construction of sports facilities and found that impacts of facility development on the local real estate market tended to vary by type of land (industrial, commercial, office). Examining property value data at different distances from the facilities (Ericsson Stadium and the Charlotte Coliseum), their analysis did not find many consistent results. As expected, land values closer to the facilities were more likely to experience a change in value than parcels at greater distances, but in many cases no impacts were discernable. Around the NFL's Ericsson Stadium, located within the Charlotte $\mathrm{CBD}$, the value of industrial land and office properties generally increased in the year prior to stadium construction (speculative inflation), but returned to their pre-stadium levels within 12 to 14 months of construction. Results for the more suburban Charlotte Coliseum, home to the NBA Charlotte Hornets, were also mixed but suggest a kind of short-term speculative run-up in land prices prior to construction. At the time of the report (about 1996), only one new business (a bar) could be directly attributable to the arena.

\section{SPORTS AS AN INDUSTRIAL COMPLEX?}

Most treatments of sports and economic development examine the four major sports in the U.S. - football, baseball, basketball, and hockey-at the major or minor league level. Undoubtedly, one professional sport that will gain increasing attention in the academic literature is NASCAR. Traditionally associated with the southeastern states, in recent years the Winston Cup and Busch Grand National NASCAR circuits have gained widespread national popularity. Since 1990, growth in attendance at NASCAR events has exceeded all other professional sports in the U.S., growing by 69 percent (the NBA ranked second with a 12 percent growth rate). Likewise, in 1997 NASCAR had become the "second highest- 
rated sport on television (not counting the playoffs in other sports) trailing only pro football" (Johnson 1999, p. 58). Deriving their revenue primarily from corporate sponsorship, most NASCAR racing teams generate $\$ 9$ to $\$ 10$ million dollars annually to support 12 cars per driver and about two dozen employees. Although there are far fewer motor speedways than stadiums and arenas (18 in 1996 as compared to 83 stadiums and arenas), several more tracks have recently opened or are under construction in areas such as Dallas-Fort Worth, Las Vegas, and Los Angeles.

One, perhaps unique, example of the economic impact of a professional sports complex is that of the Lowes Motor Speedway near Charlotte, NC (previously known as the Charlotte Motor Speedway). This speedway is an important historical locale for motor sports and a recent study has attempted to quantify its economic impact (Hartgen et al. 1996). In that report it is noted that 96 of 115 racing teams were located within 100 miles of the speedway, and that as many as 980 jobs are directly attributable, and located in close proximity to the facility. Compared to Rosentraub's (1997a) data discussed above, this facility has an important impact on the surrounding community. For example, according to County Business Patterns, 570 employees are employed in SIC 794 with annual payroll of nearly $\$ 31$ million, producing average wages that are over twice the county average in 1996 (the speedway is located in Cabarrus County, NC, part of the Charlotte MSA). As a percent of county employment, this amounts to 1.4 percent of employment and 3 percent of local payrolls, substantially higher than the data discussed above. While visitation to the speedway amounts to $679,000 \mathrm{annu-}$ ally, the proximity of racing teams to the speedway appears to have created a type of industrial complex.

In addition to the many retailers, promoters, and public relations and advertising firms that do NASCAR-related business, there are a variety of engine builders, sheet metal workers, parts producers, and other related firms that serve the race teams. Though typically employing less than 10, these firms have reported growth rates in sales of 48 percent over the previous five years. Unless NASCAR expands its number of racing circuits, not many communities can hope to generate these kinds of industrial complexes. However, it is worthy to note that the economic impact of this facility rivals those reported for teams in the four major leagues.

\section{PUBLIC SUBSIDY AND THE ECONOMIC IMPACT STUDY}

The case made for subsidizing professional sports frequently rests on the results of an economic impact assessment. As noted in Shropshire (1995), impact studies of professional teams are typically motivated by political and other special interests that either favor or oppose the use of public funds to retain teams and build facilities. Shropshire (1995) notes, for example, that a study of Philadelphia sports franchises (see Shils 1989), conducted while the Philadelphia Eagles were threatening to move to Phoenix, estimated the impact of all franchises in the city to be worth over $\$ 523$ million in 1985 and nearly $\$ 1$ billion by 1988 . Similarly, Shropshire (1995) cites a study from promoters of the 1996 Summer Olympic 
Games in Atlanta that estimated that the impact of the event would approach $\$ 3.5$ billion. Though quickly criticized for methodological flaws, these examples illustrate the political context of many impact studies.

Danielson (1997) notes that estimates of the economic impact of sports vary widely and range between $\$ 100$ million and $\$ 750$ million in "economic activity." Increasingly, analysts object to such nebulous terms as "economic activity," contending that measures of income generation are more relevant. Rosentraub (1997a) has made a strong case for basing impact estimates on income earned rather than gross sales, which is the usual approach. Using the Cleveland Indians with a 1995 payroll of $\$ 36.2$ million as an example, he shows that after accounting for the fraction of salaries that are saved by players, deflected or realigned expenditures of spectators, and salaries of nonplayers, the direct impact of the Indians is approximately $\$ 5.6$ million, to which a multiplier of 2 is applied producing a total impact of \$11.2 million (see Rosentraub 1997a, pp. 168-169).

In a thorough review of the problems with sports and recreational impact studies, Crompton (1995) has identified 11 common sources of error that inevitably inflate impact estimates: (1) the use of gross sales rather than income multipliers; (2) misrepresenting employment multipliers; (3) using incremental rather than normal multiplier coefficients; (4) failure to accurately define the impacted area; (5) including local spectators; (6) failing to exclude "time switchers" and "casuals" (those who plan a trip to a city but change the timing of the trip to coincide with an event, and visitors who attend a sports event because they are already in town); (7) using "fudged" multipliers; (8) claiming total, instead of marginal, economic benefit; (9) confusing turnover (sales) with multipliers; (10) omitting opportunity costs; and (11) measuring only benefits while omitting costs. Committing these errors does not imply a consciously biased study, but "unfortunately, abuses incorporated in an economic impact analysis are contagious because when a precedent has been established in one study, other sponsors may feel compelled to perpetuate the abuse by incorporating the misleading procedures in their own analyses" (Crompton 1995, p. 18). His results from surveys of fans at sporting events, for example, indicate that only 30 percent of visitors stated that they would not have come to the city had it not been for the event, a result remarkably close to Rosentraub's (1997a) rules of thumb. Other critics of impact studies go as far as to contend that they are "inaccurate, misleading, and unnecessary" (Hunter 1988).

The role of the impact study is not to persuade the majority of voters to support or reject subsidizing stadium construction. When the Minnesota Twins threatened to relocate to the Greensboro, NC, area, no impact study could have persuaded the majority of voters to provide a $\$ 140$ million subsidy to construct a new stadium in suburban Kernersville. That referendum was defeated with a 59 percent "no vote" in one county (Forsyth) and by a 2-to-1 margin in the other (Guilford). Indeed, the real value of the impact study is to persuade the marginal voter (Noll and Zimbalist 1997). Take, for example, a city of 1 million residents, 700,000 of whom are of voting age. Suppose the city is narrowly split with 52 
percent against a stadium bill, and 48 percent in favor of it. If voter turnout runs approximately 60 percent, the difference between the two groups of voters is 16,800 and only 8,500 would have to be persuaded to change their vote. This amounts to affecting the vote of only 1.2 percent of the voting-age public to swing the referendum. This scenario is far from implausible, as Fort (1997) has shown that many recent referenda have passed by very narrow margins.

Whether or not state and local governments should subsidize professional sports is, in the minds of many, still open to question. If professional sports are considered to be a private industry enterprise, then its subsidization might divert limited resources away from other services and be deemed socially wasteful or unfair to other businesses and taxpayers (Bast 1998). However, there is nothing new about subsidizing private sector activities, and the extension of multimillion dollar incentives to attract firms that may only employ a few hundred is commonplace. While subsidizing sports facilities is perhaps the most blatant form of corporate welfare, many locales are willing participants in their eternal search for economic development. Therefore, for many jurisdictions the relevant question is not whether to subsidize, but how much to subsidize.

It has been previously noted that government involvement in financing sports facilities should only take place if the investment yields a superior rate of return over other similar investments (Noll and Zimbalist 1997). While some government services can be justified on the basis of market failure, other government activities cannot, yet they are publicly subsidized. If professional sports are generally held to be part of a region's cultural infrastructure in the same way we view public libraries and museums, then public subsidy of sports is easily rationalized. Similarly, many symphony orchestras and opera companies, though not public services, receive sizable public subsidies. There are several factors that make professional sports different, however. First, few librarians, museum docents, or cellists are rewarded for their talents to the same extent as the utility infielder, much less a star player. Second, these types of public services have few alternative revenue sources that parallel the vast revenues teams and leagues generate through media contracts, merchandising, and other revenue sources not associated with the place in which they play. Perhaps most importantly, the local monopoly status of teams and the cartel-like characteristics of leagues ensure that teams will be kept in sufficiently limited supply so as to (a) maximize franchise value; (b) maintain market control; and (c) maintain a suitable reserve of viable, yet unserved, metropolitan areas for franchise relocation in case demands for new facilities are not met (Rosentraub 1999).

It is unlikely that the monopoly status of professional sports will be challenged in a serious way any time soon, but Ross (1991) has outlined several predictable results from dissolving sports monopolies. For the current purposes, the most important of these outcomes is that (a) leagues would vie against each other for the right to play in public stadiums, driving rents up and the tax subsidy down; (b) leagues would be eager to add new expansion markets to prevent those markets from being captured by rival leagues; and (c) because competing leagues 
would bid for players, salaries would more accurately reflect players' fair market value. In the absence of antitrust intervention, Bast (1998) comments that some scholars believe states and localities should declare a cease-fire in the bidding wars to attract professional sports. Such a strategy is unlikely to succeed, of course, because too many places want professional sports and are too willing to accommodate team owners for the privilege. As an alternative, Bast (1998) suggests that if leagues were required to restructure team revenue so that revenue from luxury suites and club boxes is shared in the same way as gate receipts, much of the incentive to relocate would be reduced, thereby limiting subsidy demands from municipalities.

Rafool (1997) provides a number of pragmatic considerations for policy makers involved in the stadium game, the first of which is simply to determine the actual need for a new stadium or arena. If claims that playing facilities are damaging franchise value or competitiveness, municipalities should determine the revenue-generating potential of existing facilities. "Does the existing stadium produce revenues? If so, would it be possible to re-negotiate the lease agreement so that the team receives a greater portion of the revenues? Does the stadium lack only lucrative luxury seating and corporate boxes? If so, how difficult would it be to add these things?" (Rafool 1997, p. 8). Although not frequently preferred by owners, these options can substantially reduce the costs of keeping a team in town.

If public subsidy turns out to be a political reality, there are several mechanisms available to minimize the tax burden on the general public. Among the most common are taxes and fees targeted at the sports-going population. Taxes on tickets, concessions, and souvenirs sold within the facility clearly resemble user fees and exact payments from the direct consumers of games. Taxes on prepared foods and beverages in areas surrounding the facility also (less accurately) target users of facilities. In Charlotte, NC, for example, the prepared food and beverage tax levied to retire the bond on a convention center generated over $\$ 9$ million in 1996. Tax Increment Financing (TIF) Districts are another option that reduces tax burden by repaying bonds with the incremental increase in property tax generated by new development. Whether used separately or in combination, such strategies address some of the distributional issues that surround the incidence of tax burden by targeting such taxes on users of facilities and consumers of games.

\section{CONCLUSIONS}

In this review I have attempted to provide a balanced discussion of the issues and impacts of professional sports. However, there is mounting evidence that professional sports facilities do not yield the economic benefits that many supporters celebrate. Incessant claims by team owners that new facilities are necessary for their clubs to remain competitive is reflective of the structure of franchise finances that have led stadiums and arenas to be economically obsolete, not physically decrepit. Despite the fact that professional sports hold a special place in the American psyche, questions have arisen as to the real income- and job-generating 
capacity of professional sports facilities. Economic impact studies are used to substantiate claims of development benefits and can influence the palatability of subsidizing professional sports.

Economic arguments for and against stadium subsidy can be made and communities must decide for themselves as to the appropriate course of action. When weighing decisions about subsidizing the construction of sports facilities, communities should take a dispassionate look at what sports mean to them, knowing that building a stadium today does not guarantee having a professional sports franchise in their city tomorrow. If voters approve subsidizing stadium construction, they should be fully cognizant of both the costs and benefits of that expenditure, noting that abandoning a usable existing facility comes at a sizable cost. It has been shown that most teams generate sufficient revenue to cover operating costs, but "no municipal stadium... has earned enough to generate a positive net accumulated value" after the fixed costs of debt and forgone property taxes have been considered (Baim 1990, p. 17).

Any taxing plan used to finance such development should be specifically targeted at the users of the facility to avoid adverse distributional tax burdens on nonusers of the facility. If a city engages in sports development, its most productive role is in land assembly and infrastructure provision. Although land and opportunity costs are higher in central city locations, the likelihood of spin-off activity and positive benefits are maximized by downtown stadium locations that integrate mixed land uses on a pedestrian scale. If voters decline to subsidize professional sports, they should also realize that the same forces that brought professional sports to their city in the first place will put their city in the running again, though it is impossible to determine when. In any event, competent, impartial analysis should be sought, the results of which should be made available to all. In addition to reasonable multiplier estimates, consideration of opportunity costs, and inclusion of externalities and welfare gains/losses, communities, taxpayers, and elected officials should insist on reports that clearly identify definitions of the impacted area, the composition of the direct effects, and assumptions concerning exports versus the amount of leisure spending realignment and direct spending leakage.

In the last analysis, the decision to subsidize is a local one. Though not an advocate of subsidizing professional sports, Rosentraub (1996), in reference to Cleveland, may have said it best:

[N]o stadium or area can affect development patterns, even at the neighborhood level...Downtown Cleveland is, once again, an entertainment and recreation center for the region... Is downtown Cleveland a more exciting place? Is there a greater sense of excitement and civic pride? Are people who long ago gave up on downtown returning for recreation? The answer to each of these questions is yes. Are these benefits or returns worth the hundreds of millions of dollars spent by taxpayers to subsidize professional 
sports?... In a city with a full set of urban challenges, is the new image created by these public investments worth the commitments if there is no direct economic impact? Is the myth or illusion of activity created by the glamour from sports and downtown crowds worth what the public sector spent? Those are questions only the residents of Cleveland and Cuyahoga County should answer (pp. 26-27, as cited in Bachelor 1998, p. 96).

\section{REFERENCES}

Baade, R. "Is There an Economic Rationale for Subsidizing Sports Stadiums?" Heartland Policy Study no. 13. Chicago: The Heartland Institute, 1987. Obtained electronically at http://www.heartland.org/ "Professional Sports as Catalysts for Metropolitan Economic Development." Journal of Urban Affairs 18 (1996), 1-17.

Baade, R., and Dye, R. "The Impact of Stadiums and Professional Sports on Metropolitan Area Development." Growth and Change 21 (1990), 1-14.

Bachelor, L. "Stadiums as Solution Sets: Baseball, Football and the Revival of Downtown Detroit." Policy Studies Review 15 (1998), 89-101.

Baim, D. "Sports Stadiums as 'Wise Investments': An Evaluation." Heartland Policy Study no. 32. Chicago, IL: The Heartland Institute, 1990. Obtained electronically at http://www.heartland.org/

Bale, J. Landscapes of Modern Sport. Leicester, UK: University of Leicester Press, 1994. Bast, J. "Sports Stadium Madness: How It Started, How To Stop It." Heartland Policy Study no 86. Chicago, IL: The Heartland Institute, 1998. Obtained electronically at http://www.heartland.org/

Beard, K., et al. The Impact of Professional Sports on Commercial Real Estate Values.

Belk College of Business Administration. Charlotte: University of North Carolina at Charlotte, n.d.

Chema, T. "When Professional Sports Justify the Subsidy: A Reply to Robert A. Baade." Journal of Urban Affairs 18 (1996), 19-22.

Crompton, J. "Economic Impact Analysis of Sports Facilities and Events: Eleven Sources of Misapplication." Journal of Sports Management 9 (1995), 14-35.

Danielson, M. Home Team: Professional Sports and the American Metropolis. Princeton, NJ: Princeton University Press, 1997.

Euchner, C. Playing the Field: Why Sports Teams Move and Cities Fight to Keep Them. Baltimore: The Johns Hopkins University Press, 1993.

Fainstein, S., and Stokes, R. "Spaces for Play: The Impacts of Entertainment Development on New York City." Economic Development Quarterly 12 (1998), 150-165.

Fort, R. "Direct Democracy and the Stadium Mess." In R. Noll and A. Zimbalist (eds:) Sports, Jobs and Taxes: The Economic Impact of. Sports Teams and Stadiums. Washington, D.C.: The Brookings Institution, 1997. 
Hamilton, B., and P. Kahn. "Baltimore's Camden Yards Ballparks." In R. Noll and A. Zimbalist (eds.) Sports, Jobs and Taxes: The Economic Impact of Sports Teams and Stadiums. Washington, D.C.: The Brookings Institution, 1997.

Hartgen , D., D. Lord, H. Campbell, A. Stewart, and D. Spawn. Survey of the Motor Sports Industry in Cabarrus, Iredell and Mecklenburg Counties. Center for Interdisciplinary Transportation Studies, Publication \#145. Charlotte: University of North Carolina at Charlotte, 1996.

Hunter, W. "Economic Impact Studies: Inaccurate, Misleading, and Unnecessary." Heartland Policy Study no. 21. Chicago, IL: The Heartland Institute, 1988. Obtained electronically at http://www.heartland.org/

Irani, D. "Public Subsidy to Stadiums: Do the Costs Outweigh the Benefits?" Public Finance Review 25 (1997), 238-253.

Johnson, R. "Speed Sells." Fortune, April 12, 1999, 56-70.

Karp, D., and W. Yoels. "Sport and Urban Life." Journal of Sport and Social Issues 14 (1990), 77-102.

Keating, R. "Squeeze Play: Do Baseball Stadiums Need Our Bucks to Get Built?" Washington Post, April 5, 1999.

Newsome, T., and Comer, J. "Changing Intra-Urban Location Patterns of Major League Sports Facilities." The Professional Geographer 52 (2000), 105-120.

Noll, R., and A. Zimbalist. Sports, Jobs and Taxes: The Economic Impact of Sports Teams and Stadiums. Washington, D.C.: The Brookings Institution, 1997.

Rafool, M. "Playing the Stadium Game." National Conference of State Legislators, 1997. Obtained electronically at http://www.ncsl.org/

Riess, S. City Games: The Evolution of American Urban Society and the Rise of Sports.

Urbana: University of Illinois Press, 1989.

"Historical Perspectives on Sport and Public Policy." Policy Studies

Review 15 (1998), 3-15.

Rosentraub, M. "Does the Emperor Have New Clothes?: A Reply to Robert Baade." Journal of Urban Affairs 18 (1996), 23-31.

. Major League Losers: The Real Cost of Sports and Who's Paying For It. New York: Basic Books, 1997a.

. "Stadiums and Urban Space," In R. Noll and A. Zimbalist (eds.) Sports, Jobs and Taxes: The Economic Impact of Sports Teams and Stadiums. Washington, D.C.: The Brookings Institution, 1997b.

. "Are Public Policies Needed to Level the Playing Field between Cities and Teams?" Journal of Urban Affairs 21 (1999), 377-395.

Rosentraub, M., D. Swindell, M. Przybylski, and D. Mullins. "Sport and Downtown Development: If You Build It, Will Jobs Come?" Journal of Urban Affairs 16 (1994), 221-239.

Ross, S. "Break Up the Sports League Monopoly." In P. Staudohar and J. Mangan (eds.) The Business of Professional Sports. Urbana: University of Illinois Press, 1991.

Santee, E. "Major League Cities." Real Estate Issues 21 (1996), 31-35. 
Shils, E. "Report to the Philadelphia Professional Sports Consortium on Its Contribution to the Economy of Philadelphia During 1988." December 4, 1989. Shropshire, K. The Sports Franchise Game: Cities in Pursuit of Sports Franchises, Events, Stadiums, and Arenas. Philadelphia: University of Pennsylvania Press, 1995. Stone, G. "Sport as a Community Representation." In G. Luther and G. Sage (eds.) Handbook of Social Science of Sport. Champaign, IL: Stipes, 1981.

Sullivan, N. "Major League Baseball and American Cities: A Strategy for Playing the Stadium Game." Policy Studies Review 15 (1998), 55-64.

Walden, M. "Economic Impacts of Residential Construction." Study prepared for the Homebuilders Association of Raleigh - Wake County (NC), 1998.

Zimbalist, A. "The Economics of Stadiums, Teams and Cities." Policy Studies Review 15 (1998), 17-29.

Zipp, J. "Spring Training." In R. Noll and A. Zimbalist (eds.) Sports, Jobs and Taxes: The Economic Impact of Sports Teams and Stadiums. Washington, D.C.: The Brookings Institution, 1997. 